\title{
A Review of Heat Transfer in Terraced Houses of Tropical Climate
}

\author{
Norazura Mizal Azzmi ${ }^{1}$, Nazhatulzalkis Jamaludin ${ }^{2}$ \\ ${ }^{1,2}$ Department of Building Surveying, UniversitiTeknologi MARA, Perak, Malaysia
}

\begin{abstract}
Heat is the process of energy circulation and replacement of air from hot to cold. In tropical climates, more heat is received because of the location of Malaysia of the equatorial line. Excessive heat in buildings causes discomfort to the occupants in tropical climate. Tropical rainforest climate receives higher solar radiation and terrestrial radiation reaching the building envelopes contributes to this problem. The design of the building should be more concern on reducing this heat. This paper provides a review of heat contribution in a terraced house indoor environment for tropical climate. A good comfortable home is part of the sustainable development agenda to improve the quality of life. Terraced houses are the most living quarters in mass living scheme for urban areas. The incoming solar energy from the sun into the building surface cannot be changed, therefore a consideration of passive building design need to be applied in terraced house design. Data collection gathered from this literature survey will assist to identify problems of discomfort occupant. This strategy would assist in improving the building industry in promoting sustainable development in Malaysia.
\end{abstract}

\section{Introduction}

Overheating is the main problem of climatic design in warm and humid climates. Compared to hot dry areas with high temperature, warm and humid climate has high relative humidity and small diurnal temperature difference caused to this problem [1]. Solar energy absorbed by the building envelops and penetrates through openings raise the indoor air temperature. As each material has different material property act alongside heat from solar energy called as thermal conductivity.

Heat in a building skin originates by three mechanisms: external heat, internal heat and ventilation. Solar radiation strike on building envelope generates external heat gains neither through opaque nor transparent materials such as windows and openings. Internal heat gain produced inside the building due to heat input of occupants, electrical appliances and artificial lighting [2].

The human body ability to measure the thermal comfort by making judgments about a space is too warm, too cool and thermally comfortable. Human thermal comfort influence by many reasons such as metabolic rate, types of clothing worn, energy radiation and heat loss from the bodily surface. There are four classical thermal environmental parameters to predict human thermal sensation [3]; humidity, air temperature, air velocity and mean radiant temperature.

Measuring these parameters help to identify the thermal sensation and variation of building design make to improve the indoor thermal environment. It is important to create comfortable and healthy indoor environment which is one the criteria considered in sustainable building assessment tools. 


\section{Heat and Building Design Interaction in Tropical Climate of Malaysia}

Malaysia located in the equatorial region, the weather is warm and humid all year. The climate characterized as high temperature and humidity. The country lies between 1 degree to 7 degree North latitude and extends from longitude of 100 degree to 119 degree east. It has a diurnal temperature range at a minimum of $23-27$ degree Celsius and a maximum of $30-34$ degree Celsius. The relative humidity ranges from 74 percent to 86 percent with evenly distributed rainfall for the whole year and usually occurs with the thunderstorm and lightning. Air movement is low and sometime become unpredictable. There two prevailing winds which dominated the monsoonal season affecting different parts of Malaysia to varying degree. The monsoons represent major changes of the wind state and rainfall that varies along the coastline of Peninsular Malaysia. The rainy season on the west coast expands from September to December, whereas the east coast receives rainfall in the months from October to February.

East Malaysia collects heavy rains between the months of November to February. Malaysia is also experiencing high solar intensity and duration that caused excessive heat in the buildings. Building surfaces such as walls, roofs and windows exposed to the sun, admitting heat from solar radiation and leading to an increase air temperature inside the building. The consumption of energy for cooling the indoor environment of the building in Malaysia is about 70 per cent [4]. In good design of building envelopes, it is essential to take into consideration the level of thermal comfort and heat transmission in warm and humid condition. The higher limit of comfortable temperature for human occupancy is 26 degrees Celsius used as the standard thermal environmental condition. The proper design of the building envelop according to Malaysia thermal expectation contribute to efficient energy and environment in the building [5].

Heat transfer is the basic mechanism of environmental effects on buildings' and occupant thermal behaviour. The most significant heat input into a building is solar radiation. In warm and humid climates, the solar radiation penetrates through the openings and solar heat gain over the building envelops during the day cause overheating of the buildings [6]. Solar radiation absorbed by building materials, gains energy and brings warms into the building. Some properties of materials may reflect the solar radiation to the environment as terrestrial radiation.

The amount of diffused solar radiation in tropical region is very high because of high content of water vapour in the air and the cloud cover in the sky. This excessive solar radiation affects the indoor thermal environment through direct radiation and absorption properties of materials. The penetrations of direct solar radiation enter the openings such as windows and heating up the internal surfaces. The absorption by building façades through conduction transferred heat into an interior space and increase the heating effects inside the buildings [7].

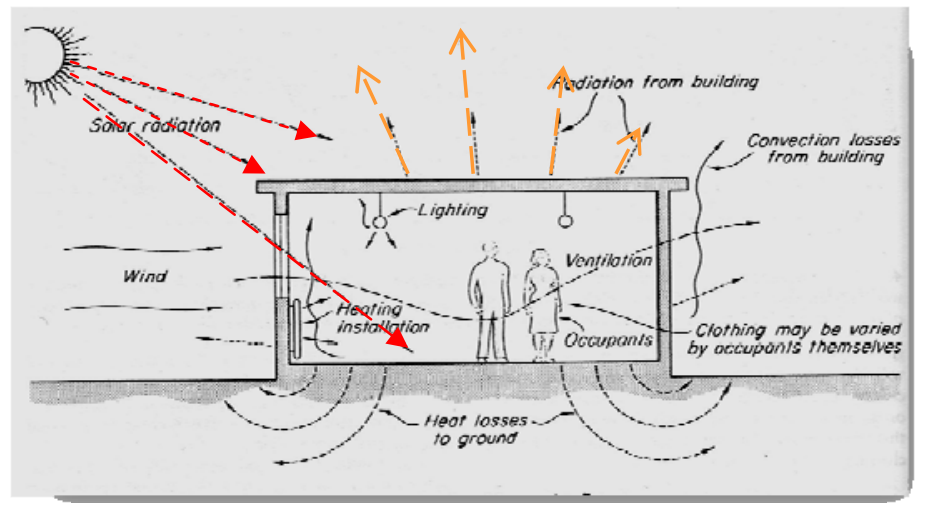

Figure 1: A thermal system of the building consist of heat outputs and inputs 
Natural ventilation is the most common cooling method in a terraced house. Recent rapid urbanization in Malaysia has increased the air-conditioning system as a cooling strategy in residential building [8]. Hence the use of active cooling will give the drawback on current energy challenge. The building industry is among the major contributors of energy needs and carbon emission. A building can be considered as a thermal system building consists of heat inputs and outputs given as the following equation [1].

The building thermal system shown in Figure 1 can be analysed firstly with the assumption in steady-state conditions where the indoor and outdoor conditions are steady, non-changing and applied as standard heat loss calculation. In this condition the diurnal changes are small and a large difference of indoor and outdoor temperatures. The effect of the thermal mass of the building can be disregarded without large error in the estimation of the heat loss. Secondly, is the building's dynamic response which assumption of design conditions for heating, ventilation and air conditioning (HVAC) system in buildings.

In a steady state condition the conduction of heat flow given as the following [1]:

$$
q_{c}=\Sigma(A \mathrm{X} U)
$$

A is the area $\left(\mathrm{m}^{2}\right)$ and $U$ is transmittance value $\left(\mathrm{W} / \mathrm{m}^{2} \mathrm{~K}\right)$

Solar heat gain in transparent (glass) measured differently with the opaque surfaces.

For transparent elements, solar gain through window is:

$$
Q_{s}=A \mathrm{X} G \mathrm{X} \theta
$$

$A$ is the area of the window $\left(\mathrm{m}^{2}\right), \mathrm{G}$ is global irradiance incident on the surface $\left(\mathrm{W} / \mathrm{m}^{2}\right)$.

The calculation of heat flow through opaque surfaces as the following (Szokolay, 2008):

$$
Q c=A \mathrm{X} U \mathrm{X}\left(T_{s a}-T_{i}\right)
$$

$T_{s a}$ is notional sol-air temperature difference for each side of the building and $T_{i}$ is internal temperature.

The extra heat flow of solar radiation for the whole building calculated separately for each side of building elements (Szokolay, 2008):

$$
\begin{array}{ll} 
& Q_{s}=q_{c} \mathrm{X} d T_{e} \\
& d T_{e}=(G \mathrm{X} \alpha-E) R_{s o} \text { for roofs } \\
& d T_{e}=G \mathrm{X} \alpha \mathrm{X} R_{s o} \quad \text { for walls } \\
& R_{s o}=(1 / h)
\end{array}
$$

$\mathrm{G}$ is global irradiance, $\alpha$ is surface absorptance, $E$ is radiant emission, $h$ is surface conductance Incorporating of passive solar design into the building is one of the strategies to control the increasing global warming [9]. The best consideration is to prevent sun rays enter the building in whatever means. Sunshine into a building heats up the high-density of building materials. After complete absorption, the saturation of heat in the material will be emitted as radiative energy into the building. This is called as thermal conduction, the transfer of heat within material properties in contact by the spread of molecular movement.

\section{Terraced Houses in Malaysia}

In the middle of the booming economy, the urban population has increased $57 \%$ from 1960 to 2010 and with more than three quarters of the Malaysia overall population estimated to settle in urban areas [10]. More land will be developed for urbanization to fulfil housing settlement due to the increasing national population. The most common typologies of residential buildings in Malaysia are terraced houses. Terrace houses are the most living quarters in mass housing scheme for urban areas. The house is reasonably cheap and common housing alternative in Malaysia [11]. In he tropical climate region, terrace houses usually experienced the warmer indoor environment caused by higher energy input from solar [12]. The study has found that the quality of housing influence by three qualities which are the house quality, the indoor environmental quality and the urban site quality [13].

The residents' satisfactions are also related to space function such as user characteristics, physical characters and beliefs of the user [14]. Human beings need well-arranged spaces to live, but the ecology of vegetation and green areas were taken into consideration in a development plan. The 
existing useful vegetation's were cut down during the construction stages accordingly to plan. It is easier to cut the tree rather than to apply in planning design. Housing layouts are important for comfortable environment, but the arrangement design irrespective of terrain, effective landscaping and direction. Uniform Building By -Law (1984) allocate 10\% for green area as required by the by most local authorities of all Malaysian states must be relooked at to measure the effectiveness. A typical single terrace house usually has built-up area about 650 - 700 square feet with 6.5 meters in front façade width and 11 meters in length. The deep floor plan surges warmer air inside the building beginning in the morning until the sunset. Terrace house usually contain of two sides opposite walls, the smaller wall exposed to the external environment. The other two remaining walls are shared with the adjacent houses.

The most common building materials for housing are cement or clay bricks for wall construction, concrete floors and concrete or clay roof tiles. These materials have a tendency for fabric heat gain into the building. The typical plastered brick wall used in the local housing development has a high heat storage capacity, which means large amounts of heat gain will be released into the room at night [15] and warming the interiorspace. Terrace house designs are not favourable for thermal comfort and occupant tend to spend more money for air-conditioning for cooling the inside environment [16]. Windows provided at front façade and the rear. The windows act as natural lighting and ventilation outlets-inlets, thus allowing the heat from solar enter the interior spaces. The limited openings trapped the hot air and cause discomfort in the house. Sun shading devices are rarely provided and aggravates internal heat gain. A study in Singapore has shown that window shading devices are effective in cooling energy consumption for east and west [17]. Normally terraced houses are arranged on a site for maximum return to the developer. As a result, several housing units are subjected to high solar gain, particularly the ones facing east and west [15].

Human activities and electrical appliances generate internal heat gain in the building. Daily activities such as cooking, watching television, the use of a fan or air-conditioning for indoor cooling, computer and electronic devices further contribute the warmer indoor environment. One-third of the monthly electricity bill in residential building is from air-conditioning system.

\section{Passive Design to Mitigate Heat From Solar Radiation in Residential Building}

Due to excessive heat and high humidity in tropical climate, the indoor thermal environment in terraced house can be improved by adapting passive design approaches. Passive design strategies developed by designer using a set of architectural design approaches so that the buildings respond adequately to climatic requirements [18]. A building designed to be responsive to the local climatic conditions is called as the Passive Architecture [19]. The climate responsive design is based on a building form and structure moderates the climates for human well-being and reduces environmental impacts [20]. Passive architecture approaches are also termed as 'green building' and 'ecological building', which is also recognised as 'healthy building' and 'energy efficient building' [21]. Therefore, passive design is a feature basis in an environmental sustainable design that relates the climate to human requirement and control excessive heat gain in the building. The sustainability concept administers three main pillars: social security, environmental safety and economic wealth [22]. Built environment activities such as construction project involved with the natural environment. Environmental safety concern with the built environment because if handled without proper planning may have a negative impact and threatening the environment. The extraction of natural resources is anxious in environmental sustainability. In passive design the designer need to consider the orientation, building form, ventilation, outdoor thermal environment, daylighting, noise pollution, sound pollution, wall insulation, roof insulation and passive cooling. In Malaysia, the passive design approach objectives to encourage natural cross ventilation for natural cooling from prevailing wind, control of heat from the solar radiation and allow enough daylight into the building. Existing provision of houses target for quantity and ignored the quality that a house should be home with a healthy environment for well-being [16]. 


\section{Conclusions}

Heat transmission induced excessive heat gains in the building. The passive design element could help to mitigate the overheating problems in residential housing for warm and humid climate. In achieving energy efficiency and indoor environmental comfort, building designers and architects are stimulating creative typologies with passive design consideration. The incorporation of sustainability elements in the building design concepts would prepare for more or green system in the sustainable building. A new mechanism to enhance sustainable development is necessary to promote the sustainable housing in Malaysia. The collaboration between researchers, building designers, suppliers and contractors need further study on technical approaches in sustainable design. There are many relevant technologies and local product related to sustainable building available in Malaysia, such as energy saving building components and equipments of high efficient building energy system. If these approaches could be effectively applied in the design and construction process of a building, the sustainability would be implemented.

\section{References}

1. Szokolay, S. V. (2008). Introduction to architectural science the basis of sustainable design (2nd ed.). USA: Architectural Press.

2. A Zain-Ahmed, (2002). Daylighting as a passive solar design strategy in tropical buildings: a case study of Malaysia. Energy Conversion and Management. Vol 43, no. 13, 1725 - 1736.

3. P. Ole Fanger and J. Toftum (2002). Extension of the PMV model to non-air-conditioned buildings in warm climates. Energy and Buildings, vol 34, no. 6, $533-536$.

4. Rahman, A. M., \& Ismail, M. R. (2008). Future design in an energy efficient building as an identity of a Malaysian tropical architecture with emphasis on photovoltaic technology and passive solar building design elements (pp. 440-449). Minden, Penang.

5. N A. Al-Tamimi and S. F. S Fadzil (2011). Thermal performance analysis for ventilated and unventilated glazed room in Malaysia (comparing simulated and field data). Indoor and Built Environment, 20(5), 534-542.

6. Rajapaksha I, Nagai H, Okumiya M. (2003). A ventilated courtyard as a passive cooling strategy in the warm humid tropics. Renew Energy, vol 28, No.11, 1755-1778.

7. NH Wong and Y Chen (2009), Tropical Urban Heat Islands climate, buildings and greenery, New York : Taylor \& Francis, (Chapter 1).

8. Ahmad, N. A., \& Abdul-Ghani, A. A. (2011). Towards Sustainable Development in Malaysia: In the Perspective of Energy Security for Buildings. Procedia Engineering, 20, 222-229.

9. A.M. Abdul Rahman, N. M. S. @ Abd.Rahim, K. Al-Obaidi, M. Ismail, and L. Yoke Mui. (2013) "Rethinking the Malaysian Affordable Housing Design Typology in View of Global Warming Considerations," Journal of Sustainable Development, vol. 6, no. 7, 134-146.

10. Jamaliah, J. (2004). Emerging trends of urbanisation in Malaysia. Journal of the Department of Statistics, Malaysia, 1, 43-54.

11. Rahim, Z. A., \& Hashim, A. H. (2012). Adapting to Terrace Housing Living in Malaysia. Procedia - Social and Behavioral Sciences, 36 (June 2011), 147-157.

12. N. Sadafi, E. Salleh, L.C Haw and Z Jaafar. (2008). Potential thermal impacts of internal courtyard in terrace houses: a case study in tropical climate. Journal of Applied Sciences, 8(15), 2770-2775.

13. Oh L. S. (2000). Housing satisfaction fo middle income households in Bandar Baru Bangi, Selangor. Dissertation, Universiti Pertanian Malaysia. (Chapter 4).

14. Altaş, N., \& Özsoy, A. (1998). Spatial adaptability and flexibility as parameters of user satisfaction for quality housing. Building and environment, 33(5), 315-323.

15. Zaki, R. W. M., Nawawi, A. H., \& Ahmad, S. S. (2012). Environmental Prospective of Passive Architecture Design Strategies in Terrace Houses, 42: 300-310. 
16. Abdul Rahman, A. M., Abd.Rahim, N. M. S. @, Al-Obaidi, K., Ismail, M., \& Yoke Mui, L. (2013). Rethinking the Malaysian Affordable Housing Design Typology in View of Global Warming Considerations. Journal of Sustainable Development, 6 (7), 134-146.

17. Wong, N. H. Ã., \& Li, S. (2007). A study of the effectiveness of passive climate control in naturally ventilated residential buildings in Singapore, 42: 1395-1405.

18. Kroner, W. (1997). An intelligent and responsive architecture. Automation in Construction, 6, 381-93

19. Zaki, W. R. M., Nawawi, A. H. \& Sh. Ahmad, S. (2007). Case study in passive architecture: energy savings benefit in a detached house in Malaysia, Proceedings in the 24th Conference on Passive and Low Energy Architecture, University of Singapore, 259-266.

20. R. Hyde. (2000), Climate responsive design, New York: E \& FN Spon, (Chapter 1)

21. Zhu, Y., \& Lin, B. (2004). Sustainable housing and urban construction in China. Energy and Buildings, 36(12), 1287-1297.

22. Addis, B., \& Talbot, R. (2001). Sustainable construction procurement: A guide to delivering environmentally responsible projects. CIRIA C571. London: CIRIA 